\title{
EFFECTS OF EDUCATION ON WOMEN'S DECISION MAKING: A STUDY OF INDEPENDENCE IN SPOUSE SELECTION IN INDIA USING IHDS-II DATASET
}

\author{
Chandan Kumar Sharma \\ Research Scholar, Jawaharlal Nehru University, New Delhi \\ DOI: 10.46609/IJSSER.2020.v05i11.016 URL: https://doi.org/10.46609/IJSSER.2020.v05i11.016
}

\begin{abstract}
This paper examines the effects of education on women's decision making for their marriages in India. It uses the Indian Human Development Survey II dataset for this purpose. Besides the effects of education, other aspects like religion, caste, age at marriage, and area of residence, which can have influences on their decision-making ability, have also been thoroughly investigated. This paper finds that marriages in India are still dominantly managed by parents with or without participation from the women. However, more educated women are more likely to opt for self-arranged (love marriage) than less educated women. About 9.5 percent of postgraduate women's total marriages are self-arranged marriages, while it is about 3.6 for illiterate women. In other words, compared to an illiterate woman, a post-graduate woman in India is more than twicelikely to choose self-arranged marriage over other types of marriages. So, education increases women's autonomy in decision-making regarding their marriage. Also, young cohorts are more likely to choose their spouse independently. Metro urban resident women across regions of residency, Christian women across religions, and Scheduled Caste women across castes have higher likelihoods of having self-arranged marriages than other women in their respective categories.
\end{abstract}

Keywords: Education, Women's Decision Making, Marriage, IHDS, India

\section{Introduction and Background}

In Indian society, marriage is almost compulsory for everyone. Traditionally, arranged marriages have been the dominant type of marriages in India. In an arranged marriage, parents and relatives take the responsibility of finding an appropriate match for a person. The person has minimal space to exercise any personal choice in an arranged marriage. Therefore, a person's marriage has a little self-dependence and a more considerable dependence on the family, relatives, and society. Arranged marriages have society's involvement and its traditional values and obligations, 


\section{International Journal of Social Science and Economic Research}

ISSN: $2455-8834$

Volume:05, Issue:11 "November 2020"

economic resources of the family, and its sentiments. There has been malpractice of dowry in arranged marriages in some parts of India. In some Indian states, child marriages have been very prevalent. But after the legislation mandating a limit to the minimum age of marriage for males and females, the incidences of child marriages have come down. Arranged marriages are very prevalent in Muslim and Hindu families, especially the higher castes of the Hindu families. Generally, women have no say in an arranged marriage.Nevertheless, in recent times, the cases of self-arranged marriages have been rising. Increasing number of self-arranged marriages are opted by the more educated persons. Self-arranged marriages or love marriages offer a person complete freedom to find a life-partner with little or no involvement of family or society. In some cases, a person selects a partner and then convinces the family to arrange their marriage with the selected partner.

There is an increasing evidence across different countries of a shift away from the parent arranged marriages to other types of marriages(for example, Kyrgyzstan (Nedoluzhko and Agadjanian, 2015) Nepal (Ghimire et al., 2006) China (Zang, 2008) Taiwan (Thornton \& Lin., 1994) Japan (Retherford and Ogawa, 2006) Indonesia (Malhotra, 1997) and Sri Lanka (Caldwell, 1999).Although, cultural norms and societal environments are very much binding in India and do not offer enough liberty to young adults to select their partner entirely by themselves, an increasing number of young adults do not want their parents to select their spouse for them in recent times. So, the middle-ground is gaining popularity. In this case, selecting a spouse with the help of parents is easier. Selecting a spouse and then involving parents to arrange a marriage is easier than taking the entire decision altogether by the individuals. This kind of arrangement not only offers a greater say to young adults, in comparison to fully arranged marriages, it also keeps the cultural norms and societal environment related to marriages continuing, and parents control over their children's marriages with some flexibility (Medora, 2003).In the Indian context, the available literature on marriage has its main focus on the age at marriage and the cultural practice of dowry in the case of India, and there is an acute shortage of literature focusing on factors which play an important role for youths, in particular women, in selecting their life partner (Malhotra 1991). According to Banerji etal. (2013), there is a lack of national studies on the trends in marriage types in India. The agency of the women taking decision for marriages has been understudied. Many studies are available based on small sample surveys, but there is an acute shortage of empirical work at the national level in India.

Against this background, this paper's main objective is toinvestigate the effects of education on the type ofmarriage chosen by the women in India with the use of the most recent dataset available. More specifically, this study tries to check if there is a change in the trend of marriages in India, i.e., if moreeducated women are choosing self-arranged marriages over the other types of marriages in India. The study also tries to find out the effects of other important variables like 
International Journal of Social Science and Economic Research

ISSN: 2455-8834

Volume:05, Issue:11 "November 2020"

castes, religions, area of residence, and age on the choice of marriage types.This paper is divided into five sections. Section two elaborates on the data sources and methodology. Section three discusses the findings of the descriptive analysis, while section four is devoted to the econometric analysis and results discussion. Section five concludes the paper.

\section{Data Sources and Methodology}

For this paper, initial ideas have been taken from Banerji et al. (2013). But this study uses a different year dataset, a different econometric model with some other significant changes. The Indian Human Development Survey-II (2011-12), IHDS-II henceforth, has been used for this study. According to Banerji et al. (2013), IHDS is the only survey that can be used for this kind of study at the national level in India. The household data and the eligible women data have been used together to get all the variables related to this study. The two data sets have been merged using the dataset guidelines. Also, for all the calculations, appropriate weights have been used. IHDS-II is a nationally representative survey with a vast number of topics. There is one earlier survey, IHDS-I (2004-05), but the IHDS-II is the latest available dataset in the public domain at the time of this analysis. IHDS-II surveyed 42,152 households in 1,503 villages and 971 urban neighbourhoods across India. For this study, economics software STATA has been used.This study has been done in two ways. First, extensive descriptive analysis has been presented. Second, logit regression model has been used to investigate the main questions. The odds ratios and marginal effects at mean have also been calculated for further discussion.

The selection of women as a respondent has been based on some restrictions. Here, the main focus of the study is on the women with present age 25-49 years who were married once and the age of marriage was between 15 and 24 years. According to IHDS II data set, 83.19 percent of total marriages happened in the ages 15-24 years. After considering all these restrictions, the sample size reduces to 24,953 observations. All the women in the sample have been categorized into five birth cohorts, each of five years (from 1963-67 to 1983-87), seven levels of education (from illiterate to post-graduate), five categories for age at first marriage (15-16 years to 23-24 years), three areas of residence (rural to metro urban), five religion categories, and six caste categories.

\section{Descriptive Analysis}

In IHDS data, all the marriages can be categories into four kinds; namely, self-arranged marriages (or love marriages), jointly arranged marriages, parents arranged marriages with participation from the women, and parent arranged marriages without participation from the women. The jointly arranged marriage means the women and the parents jointly take decisions in 
choosing the groom. In this category of marriages, the woman has more say than in the third category of marriage.

For the full cohort, the most common response is for the parent arranged marriages with no participation from the women (at 38.57 percent), 33.11 percent of the total marriages are parent arranged marriages with the participation of the women, 23.13 percent of total marriages are jointly arranged marriages. In contrast, the percent of our interest i.e., the self-arranged marriages, is about 5 per cent of total marriages.From the oldest birth cohort (1963-67) to the recent one (1983-87), the percentage of self-arranged marriage has marginally increased; 1.6 percentage points (from 3.71 per cent to 5.31 percent). The most significant increase comes in the parent arranged marriages with participation from the women. It increases by about nine percentage points (from 28.43 per cent to 37.64 per cent) while there is a fall of 12 percentage points (from 44.44 per cent to 32.40 per cent) in the parent arranged marriages without participation from the women. Therefore, significant changes can be seen in the parent arranged marriages (Table 1).

Table 1: Distribution of marriage types for women (present age 25-49 years) who entered the first marriage in the ages 15-24 years, by birth cohorts

\begin{tabular}{ccccc}
\hline \hline & Self-arranged marriages & $\begin{array}{c}\text { Jointly arranged } \\
\text { marriages }\end{array}$ & $\begin{array}{c}\text { Parent arranged marriages } \\
\text { with participation from the } \\
\text { respondent (women) }\end{array}$ & $\begin{array}{c}\text { Parent arranged marriages } \\
\text { with no participation from } \\
\text { the respondent (women) }\end{array}$ \\
\hline Full Cohort & 04.73 & 23.13 & 33.11 & 38.57 \\
$1963-67$ & 3.71 & 23.05 & 28.43 & 44.44 \\
$1968-72$ & 4.46 & 22.38 & 30.70 & 41.88 \\
$1973-77$ & 4.95 & 21.79 & 33.60 & 39.09 \\
$1978-82$ & 5.04 & 23.85 & 34.05 & 36.54 \\
$1983-87$ & 5.31 & 24.40 & 37.64 & 32.40 \\
\hline
\end{tabular}

Source: Author's calculation based on IHDS II (2011-12) data sets.

Furthermore, it is observed that as the level of education increases, the percentage of women opting for self-arranged marriages increases. In the illiterate category, about 3.6 percent of total marriages are self-arranged, which increases with education and reaches 9.2 percent in the postgraduate category. But surprisingly, such increments are sharper for the jointly arranged marriages, and parent arranged marriages with the women's participation. Postgraduate women are more likely to report parent arranged marriages with consent in comparison to illiterate women. The biggest difference is for the parent arranged marriages with no participation of the women. We see that there is a continuous sharp decline in the percentage of marriages in this category as the level of education improves (Table 2). 
International Journal of Social Science and Economic Research

ISSN: 2455-8834

Volume:05, Issue:11 "November 2020"

Table 2: Distribution of marriage types for women (present age 25-49 years) who entered the first marriage in the ages 15-24 years, by levels of education

\begin{tabular}{lcccc}
\hline \hline Levels of Education & Self-arranged marriages & $\begin{array}{c}\text { Jointly arranged } \\
\text { marriages }\end{array}$ & $\begin{array}{c}\text { Parent arranged marriages } \\
\text { with participation from the } \\
\text { respondent (women) }\end{array}$ & $\begin{array}{c}\text { Parent arranged marriages } \\
\text { with no participation from } \\
\text { the respondent (women) }\end{array}$ \\
\hline illiterate & 3.55 & 19.00 & 24.84 & 52.23 \\
Primary & 4.63 & 21.15 & 33.25 & 40.53 \\
Upper Primary & 4.91 & 24.68 & 36.22 & 33.74 \\
Secondary & 6.03 & 26.73 & 40.61 & 25.99 \\
Senior Secondary & 5.42 & 32.24 & 42.11 & 19.63 \\
College & 7.25 & 30.34 & 46.36 & 15.76 \\
Post Graduate & 9.24 & 31.87 & 46.08 & 12.63
\end{tabular}

Source: Author's calculation based on IHDS II (2011-12) data sets.

There is a very small increase in the percentage of total marriages as self-arranged marriages as we move from the rural areas to metro urban areas (from 4.74 per cent to 4.88 per cent), while there is a huge fall in the percentage of parent arranged marriages with no participation from the women (from 43.64 per cent to 29.13 per cent) in the same case. The highest percentage points of jointly arranged marriages and parent arranged marriages with participation from the women are 29.71 per cent in metro urban areas and 44.13 per cent in other urban areas, respectively (Table 3).

Table 3: Distribution of marriage types for women (present age 25-49 years) who entered the first marriage in the ages 15-24 years, by area of residence

\begin{tabular}{ccccc}
\hline \hline Current Residence & $\begin{array}{c}\text { Self-arranged } \\
\text { marriages }\end{array}$ & $\begin{array}{c}\text { Jointly arranged } \\
\text { marriages }\end{array}$ & $\begin{array}{c}\text { Parent arranged marriages } \\
\text { with participation from the } \\
\text { respondent (women) }\end{array}$ & $\begin{array}{c}\text { Parent arranged marriages } \\
\text { with no participation from } \\
\text { the respondent (women) }\end{array}$ \\
\hline Rural & 4.74 & 20.60 & 30.66 & 43.64 \\
Metro Urban & 4.88 & 29.71 & 35.58 & 29.13 \\
Other Urban & 4.24 & 22.05 & 44.13 & 29.27 \\
\hline
\end{tabular}

Source: Author's calculation based on IHDS II (2011-12) data sets.

Table 4: Distribution of marriage types for women (present age 25-49 years) who entered the first marriage in the ages 15-24 years, by religion

\begin{tabular}{lcccc}
\hline \hline Religions & $\begin{array}{c}\text { Self-arranged } \\
\text { marriages }\end{array}$ & $\begin{array}{c}\text { Jointly arranged } \\
\text { marriages }\end{array}$ & $\begin{array}{c}\text { Parent arranged marriages } \\
\text { with participation from the } \\
\text { respondent (women) }\end{array}$ & $\begin{array}{c}\text { Parent arranged marriages } \\
\text { with no participation from } \\
\text { the respondent (women) }\end{array}$ \\
\hline Hindu & 04.41 & 23.02 & 33.10 & 39.05 \\
Muslim & 04.28 & 22.49 & 32.57 & 40.12 \\
Christian & 14.57 & 38.54 & 30.73 & 3.46 \\
Sikh and Jain & 03.09 & 11.35 & 36.86 & 48.27
\end{tabular}


International Journal of Social Science and Economic Research

ISSN: 2455-8834

Volume:05, Issue:11 "November 2020"

$\begin{array}{lllll}\text { Other Religion } & 13.82 & 26.82 & 36.73 & 22.63\end{array}$

Source: Author's calculation based on IHDS II (2011-12) data sets.

Table 5: Distribution of marriage types for women (present age 25-49 years) who entered first marriage in the ages 15-24 years, by caste

\begin{tabular}{lcccc}
\hline \hline Castes & $\begin{array}{c}\text { Self-arranged } \\
\text { marriages }\end{array}$ & $\begin{array}{c}\text { Jointly arranged } \\
\text { marriages }\end{array}$ & $\begin{array}{c}\text { Parent arranged marriages } \\
\text { with participation from the } \\
\text { respondent (women) }\end{array}$ & $\begin{array}{c}\text { Parent arranged marriages } \\
\text { with no participation from } \\
\text { the respondent (women) }\end{array}$ \\
\hline Brahmins & 03.93 & 19.05 & 32.06 & 44.86 \\
Other High Castes & 05.54 & 25.03 & 36.29 & 32.64 \\
OBCs & 02.79 & 23.65 & 31.56 & 41.62 \\
SCs & 03.98 & 21.65 & 32.97 & 40.75 \\
STs & 13.60 & 20.62 & 31.44 & 33.91 \\
\hline
\end{tabular}

Source: Author's calculation based on IHDS II (2011-12) data sets.

On the religion and caste fronts, Christian women reported the highest percentage of love marriages (14.57 per cent) as compared to types of marriages across the religions. The four kinds of marriages record almost the same percentage points for the Hindu and Muslim women (Table 4). Across caste categories, ST women are the most likely caste category to report their marriages as love marriage (13.60 per cent) as compared to other castes (Table 5). The parent arranged marriages with no participation from the women are most prevalent among the Brahmin households in India.

\section{Econometric Analysis and Results Discussion}

In this section, the logit model, marginal effects at the mean, and the odds ratios have been used. The dependent variable is self-arranged marriages, which takes value one if the marriage reported is a self-arranged marriage and 0 otherwise. While the independent variables are birth cohorts, levels of education, religions, castes, age at marriage, and residence area.

Table 6 reports the results of the logit regression model ${ }^{1}$, marginal effects, and odds ratios. While the sign of the coefficient of the logit model indicates whether the variable has a positive or a negative effect on the dependent variable, the marginal effects and odds ratios give a substantive measure. As we move from 1963-67 birth cohort to 1983-87 birth cohort, we move from older to a younger cohort of women. Logit coefficients related to all the birth cohorts have positive signs, which substantiate that in comparison to the oldest birth cohort (1963-67), the newer one has more chances to report their marriages as love marriage. The marginal effect for all the birth cohorts is more or less the same. The odds ratios are the most important things in terms of the analysis of the results here. We see that in comparison to the reference category birth cohort, the

\footnotetext{
${ }^{1}$ The results tables shows the values of the standard errors of coefficients in the parentheses just below the value of the coefficients.
} 
International Journal of Social Science and Economic Research

ISSN: 2455-8834

Volume:05, Issue:11 "November 2020"

recent birth cohort women are more likely to report their marriage as love marriage. Therefore, we find that as we move from the oldest to youngest cohort women, the likelihood that they will report more and more their marriages as self-arranged (love-marriages). Furthermore, as noticed in the descriptive analysis above, education has a positive impact on the probability of reporting marriages as love marriages by the women except in the upper primary education level as we find that the magnitude of the odds increases from the primary level of education to the postgraduate level, except the upper primary level(Table 6). We see that there is a substantive increase in the odds ratios in the higher education sections. In comparison to illiterate, primary, upper primary, secondary, and senior secondary, the college level and the post-graduate level educated women are more likely to report their marriages are love marriages. In fact, the postgraduate women are more than twice likely to report their marriage as love marriages in comparison to the illiterate women (Table 6).

Furthermore, women in the metro urban areas are more likely to report their marriages as love marriages in comparison to the women in the rural and the other urban areas. In comparison to the Hindu women, the Christian women are more likely to report their marriage as love marriage, and in comparison to the Brahmin women, the women belonging to STs castes are more likely to report their marriages as love marriage (Table 6).

Table 6: Results of the Logit Regression Model

\begin{tabular}{|c|c|c|c|}
\hline $\begin{array}{l}\text { Self-arranged marriages vs. other types of } \\
\text { marriages. }\end{array}$ & Logit Model & Marginal Effects & Odds Ratio \\
\hline \multicolumn{4}{|l|}{ Birth Cohorts } \\
\hline \multicolumn{4}{|l|}{ 1963-67 (Reference Category) } \\
\hline \multirow[t]{2}{*}{$1968-72$} & $0.255^{* *}$ & $0.011^{* *}$ & $1.291^{* *}$ \\
\hline & (0.109) & $(0.005)$ & $(0.140)$ \\
\hline \multirow[t]{2}{*}{ 1973-77 } & $0.253^{* *}$ & $0.010^{* *}$ & $1.288^{* *}$ \\
\hline & $(0.107)$ & $(0.005)$ & $(0.137)$ \\
\hline \multirow[t]{2}{*}{$1978-82$} & $0.254^{* *}$ & $0.010^{* *}$ & $1.289 * *$ \\
\hline & $(0.108)$ & $(0.005)$ & (0.139) \\
\hline \multirow[t]{2}{*}{$1983-87$} & $0.307^{* * *}$ & $0.013^{* * *}$ & $1.360 * * *$ \\
\hline & $0.107)$ & $(0.005)$ & $(0.145)$ \\
\hline \multicolumn{4}{|l|}{ Levels of Education } \\
\hline \multicolumn{4}{|l|}{ illiterate (Reference Category) } \\
\hline \multirow[t]{2}{*}{ Primary } & $0.345^{* * *}$ & $0.015^{* * *}$ & $1.411^{* * *}$ \\
\hline & $(0.097)$ & $(0.005)$ & $(0.137)$ \\
\hline \multirow[t]{2}{*}{ Upper Primary } & $0.296 * * *$ & $0.012^{* * *}$ & $1.344 * * *$ \\
\hline & $(0.102)$ & $(0.005)$ & $(0.137)$ \\
\hline
\end{tabular}


International Journal of Social Science and Economic Research

ISSN: 2455-8834

Volume:05, Issue:11 "November 2020"

\begin{tabular}{|c|c|c|c|}
\hline \multirow[t]{2}{*}{ Secondary } & $0.440 * * *$ & $0.019 * * *$ & $1.553^{* * *}$ \\
\hline & $(0.099)$ & $(0.005)$ & $(0.154)$ \\
\hline \multirow[t]{2}{*}{ Senior Secondary } & $0.398^{* * *}$ & $0.018^{* * *}$ & $1.489 * * *$ \\
\hline & $(0.131)$ & $(0.007)$ & $(0.195)$ \\
\hline \multirow[t]{2}{*}{ College } & $0.578^{* * *}$ & $0.028^{* * *}$ & $1.782^{* * *}$ \\
\hline & (0.149) & $(0.007)$ & $(0.266)$ \\
\hline \multirow[t]{2}{*}{ Post Graduate } & $0.861^{* * *}$ & $0.049 * * *$ & $2.366^{* * *}$ \\
\hline & $(0.202)$ & $(0.016)$ & $(0.478)$ \\
\hline \multicolumn{4}{|l|}{ Age at Marriage (in Yrs.) } \\
\hline \multicolumn{4}{|c|}{ 15-16 (Reference Category) } \\
\hline \multirow[t]{2}{*}{$17-18$} & 0.051 & 0.002 & 1.052 \\
\hline & $(0.088)$ & $(0.003)$ & $(0.092)$ \\
\hline \multirow[t]{2}{*}{$19-20$} & $0.201^{* *}$ & $0.008^{* *}$ & $1.223^{* *}$ \\
\hline & $(0.096)$ & $(0.004)$ & $(0.117)$ \\
\hline \multirow[t]{2}{*}{$21-22$} & $0.465^{* * *}$ & $0.021 * * *$ & $1.592^{* * *}$ \\
\hline & $(0.109)$ & $(0.006)$ & $(0.173)$ \\
\hline \multirow[t]{2}{*}{$23-24$} & $0.314^{* *}$ & $0.014^{* *}$ & $1.369 * *$ \\
\hline & $(0.133)$ & $(0.007)$ & $(0.182)$ \\
\hline \multicolumn{4}{|l|}{ Current Residence } \\
\hline \multicolumn{4}{|c|}{ Rural (Reference Category) } \\
\hline \multirow[t]{2}{*}{ Metro Urban } & -0.001 & 0.000 & 0.999 \\
\hline & $(0.119)$ & $(0.005)$ & $(0.119)$ \\
\hline \multirow[t]{2}{*}{ Other Urban } & $0.211^{* * *}$ & $0.008^{* *}$ & $1.235^{* * *}$ \\
\hline & $(0.072)$ & $(0.003)$ & $(0.089)$ \\
\hline \multicolumn{4}{|l|}{ Religion } \\
\hline \multicolumn{4}{|c|}{ Hindu (Reference Category) } \\
\hline \multirow[t]{2}{*}{ Muslim } & 0.143 & 0.006 & 1.153 \\
\hline & $(0.101)$ & $(0.004)$ & $(0.117)$ \\
\hline \multirow[t]{2}{*}{ Christian } & $0.877^{* * *}$ & $0.050 * * *$ & $2.404 * * *$ \\
\hline & $(0.131)$ & $(0.011)$ & $(0.314)$ \\
\hline \multirow[t]{2}{*}{ Sikh + Jain } & $-0.988 * * *$ & $-0.025^{* * *}$ & $0.372^{* * *}$ \\
\hline & $(0.275)$ & $(0.004)$ & $(0.102)$ \\
\hline \multirow[t]{2}{*}{ Other Religion } & $0.798^{* * *}$ & $0.044 * * *$ & $2.220 * * *$ \\
\hline & $(0.180)$ & $(0.014)$ & $(0.401)$ \\
\hline \multicolumn{4}{|l|}{ Caste } \\
\hline \multicolumn{4}{|c|}{ Brahmins (Reference Category) } \\
\hline \multirow[t]{2}{*}{ Other High Castes } & $0.293^{* *}$ & $0.012 * * *$ & $1.341^{* *}$ \\
\hline & $(0.143)$ & $(0.006)$ & $(0.192)$ \\
\hline OBCs & $-0.341 * *$ & $-0.013^{* *}$ & $0.711^{* *}$ \\
\hline
\end{tabular}




\begin{tabular}{|c|c|c|c|}
\hline & $(0.145)$ & $(0.005)$ & $(0.103)$ \\
\hline \multirow[t]{2}{*}{ SCs } & 0.070 & 0.003 & 1.073 \\
\hline & $(0.153$ & $(0.006)$ & $(0.164)$ \\
\hline \multirow[t]{2}{*}{ STs } & $1.029 * * *$ & $0.060^{* * *}$ & $2.797^{* * *}$ \\
\hline & (0.159) & $(0.013)$ & $(0.444)$ \\
\hline \multirow{2}{*}{ Other Castes } & $0.465^{*}$ & 0.022 & $1.592^{*}$ \\
\hline & $(0.257)$ & $(0.015)$ & $(0.410)$ \\
\hline \multirow[t]{2}{*}{ Constant } & $-3.900^{* * *}$ & $\ldots .$. & $0.020^{* * *}$ \\
\hline & $(0.171)$ & $\ldots .$. & $(0.003)$ \\
\hline No. of Iterations & 4 & $\ldots .$. & $\ldots .$. \\
\hline Log Likelihood & -4384.352 & $\ldots .$. & -4384.352 \\
\hline Number of Obs. & 24329 & $\ldots .$. & 24329 \\
\hline LR Chi^2 & 447.330 & $\ldots .$. & 447.330 \\
\hline Prob $>\mathrm{Chi}^{\wedge} 2$ & 0.000 & $\ldots .$. & 0.000 \\
\hline Pseudo $R^{\wedge} 2$ & 0.049 & $\ldots .$. & 0.049 \\
\hline
\end{tabular}

Source: Author's calculation based on IHDS II (2011-12) data sets.

\section{Conclusion}

Although in the descriptive analysis of this paper, we found that the highest percentage of total marriages is 38.57 per cent in "the parent arranged marriages with no participation of the women" category of marriage and the lowest percentage of all marriages (about 5 per cent) in the love marriage category, we found the substantive evidence of the younger women more likely to opt for love marriage than the older ones, both descriptively and econometrically. Furthermore, we found that the more educated women are more likely to report their marriages as love marriages in comparison to illiterate or less educated women. Post-graduate women are more than twice likely to report their marriage as love marriages in comparison to the illiterate women. So, education plays an important role on the agency of women decision-making regarding their marriage. We also found that the metro urban resident women are more likely to have love marriage than women in the rural or the other urban areas. In the religion aspect, Christian women have the highest likelihood of having a love marriage in comparison to Hindu women and other religion women. Scheduled Caste women have the highest likelihood of having love marriages in comparison to Brahmin and other caste women. Some more interesting results can be obtained if we focus separately on the other three kinds of marriages also, which requires a considerable amount of time and effort and can be researched in the future. 
International Journal of Social Science and Economic Research

ISSN: 2455-8834

Volume:05, Issue:11 "November 2020"

\section{Reference:}

1. Banerji, M., Martin, S., \& Desai, S. (2013). Are the young and educated more likely to have 'love'than arranged marriage? A study of autonomy of partner choice in India. Working Paper Series (pp. 1À43). New Delhi: NCAER.

2. Caldwell, B. (1999). Marriage in Sri Lanka: A century of change. New Delhi: Hindustan Pub. Corp.

3. Desai, Sonalde, and Reeve Vanneman. India Human Development Survey II (IHDSII), 201112. ICPSR36151v2. Ann Arbor, MI: Interuniversity Consortium for Political and Social Research [distributor], 20150731. http://doi.org/10.3886/ICPSR36151.v2.

4. Ghimire, D. J., Axinn, W. G., Yabiku, S. T., \& Thornton, A. (2006). Social change, premarital nonfamily experience, and spouse choice in an arranged marriage society. American Journal of Sociology, 111(4), 1181-1218.

5. Malhotra, A. (1991). "Gender and Changing Generational Relations: Spouse Choice in Indonesia”, Journal of Marriage and Family, 28 (4): 549-570.

6. Malhotra, A. (1997). Gender and the timing of marriage: Rural-urban differences in Java. Journal of Marriage and the Family, 434-450.

7. Medora, N. (2003). "Mate Selection in Contemporary India: Love Marriages Versus Arranged " in in R. Hamon and B. Ingoldsby (eds.) Mate Selection across Cultures. Thousand Oaks: Sage Publications.

8. Nedoluzhko, L., \& Agadjanian, V. (2015). Between tradition and modernity: Marriage dynamics in Kyrgyzstan. Demography, 52(3), 861-882.

9. Retherford Robert D, Ogawa Naohiro. Japan's Baby Bust: Causes, Implications, and PolicyResponses. In: Harris Fred R., editor. The Baby Bust: Who Will Do the Work? Who Will Pay theTaxes? Lanham, MD: Rowman \& Littlefield Publishers, Inc; 2006

10. Thornton, A., \& Lin, H. S. (1994). Social change and the family in Taiwan. University of Chicago Press.

11. Wooldridge, J. M. (2010). Econometric analysis of cross section and panel data. MIT press.

12. Zang, X. (2008). Gender and ethnic variation in arranged marriages in a Chinese city. Journal of Family Issues, 29(5), 615-638. 